\title{
Mapping and Analysis of Initial cost Against Levelized Cost of Energy for Residential PV Rooftoop in Indonesia
}

\author{
Riadhi Fairuz ${ }^{1}$, Eko Adhi Setiawan ${ }^{* 1,2}$ and , Ikhsan Hernanda ${ }^{1}$ \\ ${ }^{1}$ Electrical Engineering, Electrical Engineering Department, Universitas Indonesia, Depok, Indonesia \\ ${ }^{2}$ Tropical Renewable Centre, Faculty of Engineering, Universitas Indonesia, Depok, Indonesia
}

\begin{abstract}
Future electricity tariffs are expected to increase. To overcome this condition, arise the idea how the residential can generate its own electricity by exploiting the potential of solar energy. However, there are some constraints in its implementation due to the difference of the initial cost and sales from solar PV systems in various region of Indonesia. The purpose of this study is to determine the impact of initial cost on the levelized cost of energy from the system. This study uses the calculation of Levelized Cost of Energy ( $\mathrm{LCOE}$ ) and economic feasibility analysis through the calculation of net present value with net metering scheme. Manado is the most optimal city to implement this system. The initial cost will affect to the LCoE, the high initial cost can be covered by the amount of cash flow generated by the system which has huge solar irradiation potentials.
\end{abstract}

\section{Introduction}

Indonesia's location on the equator makes solar radiation can continue throughout the year without experiencing seasonal constraints. The average potential of solar irradiation in Indonesia is $4.8 \mathrm{kWh} / \mathrm{m}^{2}$ but it has not been well utilized and only used for conventional and does not focus on electric power generation. Increasing the number of population and the economic development of a country so that the amount of energy demand will also increase. Most of the energy is supplied by PLN (Perusahaan listrik negara) is obtained from fossils fuel. In the utilization of fossil energy, the government allocates subsidy funds that cost the state budget for $33.7 \%$ of the total annual budget of Indonesia. Based on Regulation of the Minister of Energy and Mineral Resources number 41 of 2017, the electricity tariff price in non-subsidized groups in every three months will varies. It depends to the price of Indonesian crude oil, inflation rate and the currency. As a result, there is uncertainty over the price of public electricity tariffs, especially for non-subsidized customers. Based on the data of electricity tariffs in 2015 - 2017, electricity tariff prices tend to increase. With existing data, it is predicted that there will be an increase in the price of electricity tariff in the future. From this phenomenon, arise an idea about how the house is not to depend on the electricity sold by PLN. In other words, every home can generate its own electrical energy and when excess energy is produced, its energy can be sold to PLN. In this paper will be discussed about the possibility to generate photovoltaic-based electrical energy residential in some areas of Indonesia with the price trend of PV systems that decrease every year and the price of electricity tariffs to increase. The areas in this simulation are representations of cities in 5 major islands in Indonesia. The farther the location of the central sales system will be the more expensive initial cost. this is due to the influence of shipping costs, packaging cost, transportation costs of expert technicians, and expert technician allowance. this becomes the concentration in this paper to find out how much influence the initial cost against the potential of sunlight in each area of simulation. This paper will also compare the impact of system implementation in 2018 and the system implementation during the year of Grid Parity. Electrical energy sales mechanism will use net metering system in accordance with the rules of directors of PT PLN. 0733.K / DIR / 2013. The project analysis will be conducted for 20 years.

\section{Methodology}

The System Advisor Model (SAM) software is used to design and make financial analysis for these cases. In this research, we use residential on-grid system with net metering scheme in five big cities that represent of the five major islands of Indonesia. In the net metering system there will be a mechanism of buying and selling energy between homeowners and electricity sellers (PLN). The price of electricity generated by home that sold to PLN will be equal to the electricity tariffs paid by the house every day. That means that to achieve maximum profit in the installation of this on-grid system then the house must know the LCoE (levelized cost of energy) on the installed system. LCoE can be interpreted

\footnotetext{
Corresponding author: ekoas@eng.ui.ac.id.
} 
as the minimum capital cost from the system to generate $1 \mathrm{kWh}$ during the analysis period which is converted to the present value [4].

$$
\text { Levelized cost (real) }=\frac{-c_{0}-\frac{\sum_{n=1}^{N} c_{n}}{\left(1+d_{\text {nominal }}\right)^{n}}}{\frac{\sum_{n=1}^{N} l_{n}}{\left(1+d_{\text {real }}\right)^{n}}}
$$

With:

$\begin{array}{ll}\mathrm{Co} & : \text { Initial cost } \\ \mathrm{N} & \text { : The term of project analysis } \\ \mathrm{Cn} & \text { : Operational cost in year } \mathrm{n} \\ \text { dnominal } & \text { : Discount rate } \\ \text { Qn } & : \text { The energy produced in the nth year }\end{array}$

LCoE is affected by the investment cost of installation. Considering that Indonesia is not a continental country but is an archipelago nation, the cost of delivering goods to location that far from the system sales center will have additional costs. In this research we will find out the influence of initial cost to LCoE in five cities. In addition, the SAM software also provides other analysis such as Net Present Value (NPV) and Payback period.

$$
\mathrm{NPV}=\sum_{n=0}^{N} \frac{C_{n}}{\left(1+d_{\text {nominal }}\right)^{n}}
$$

With:

$\mathrm{Cn} \quad$ : Cash flow after tax at year $\mathrm{n}$

$\mathrm{N} \quad$ : Project analysis period

Dnominal : Discount Rate with inflation

$$
P B=n+\frac{(a-b)}{(c-b)} \times 1 \text { Tahun }
$$

With:

n : The last year wich the amount of cash flow has not been able to cover the initial cost

a : Amount of initial investment

b : Cumulative sum of cash flow in year $n$

c : Cumulative sum of cash flow in $n+1$ years

NPV can be interpreted as a net profit received by the system by making energy savingsa due to the mechanism of sale and purchase in the future that is converted to the present value. Payback period is the duration the system the return the capital cost. Payback period is used as reference for the owner to decide the system development. Simulation method conducted by SAM for this research can be seen in the flow diagram below [2].

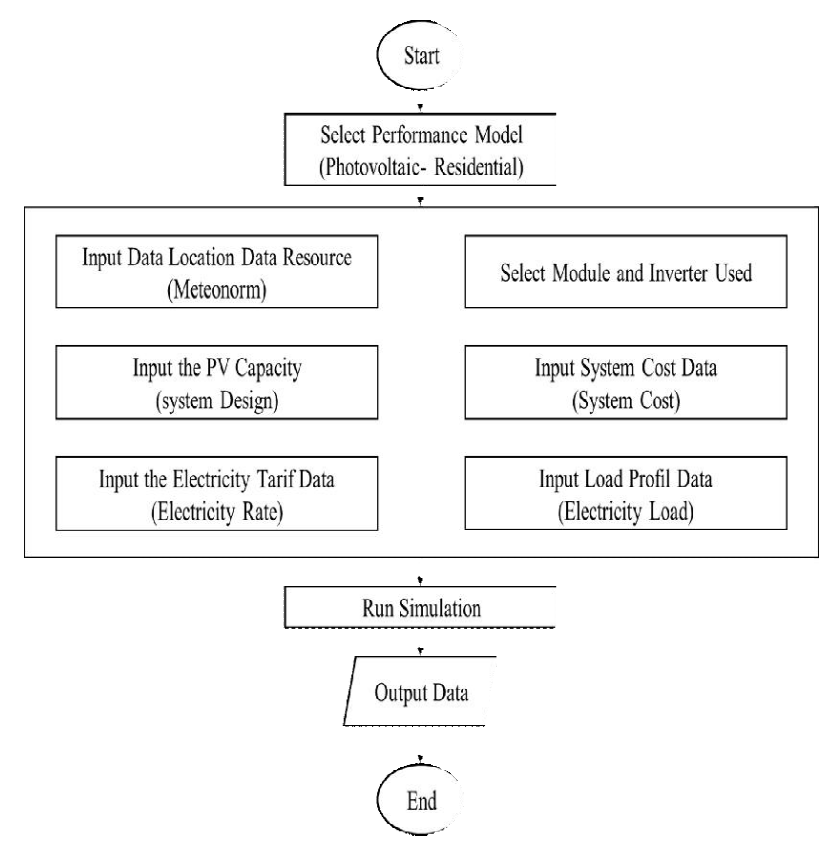

Fig 1. Flow Diagram

\section{Result and Analysis}

The forecasting data shows the intersection between BPP (Biaya Pokok Penyediaan) PLN and LCoE. The year of grid parity means the year of the PV investment system generated by home economically can compete with Electricity generated by PLN [1]. Then it can be assumed in that year there will be a new policy from government regarding PV system sales considering at that time the government has incentive cost incurred on electricity buying mechanism. Grid parity in Indonesia did not occur simultaneously in the same year due to the effect of delivery cost and different PV irradiation on each location. The fastest grid parity occurs in 2019 in Jakarta and Manado, followed by Banda Aceh and Jayapura in 2020, and Balikpapan in 2021. Grid parity charts of each city can be seen in the figures below

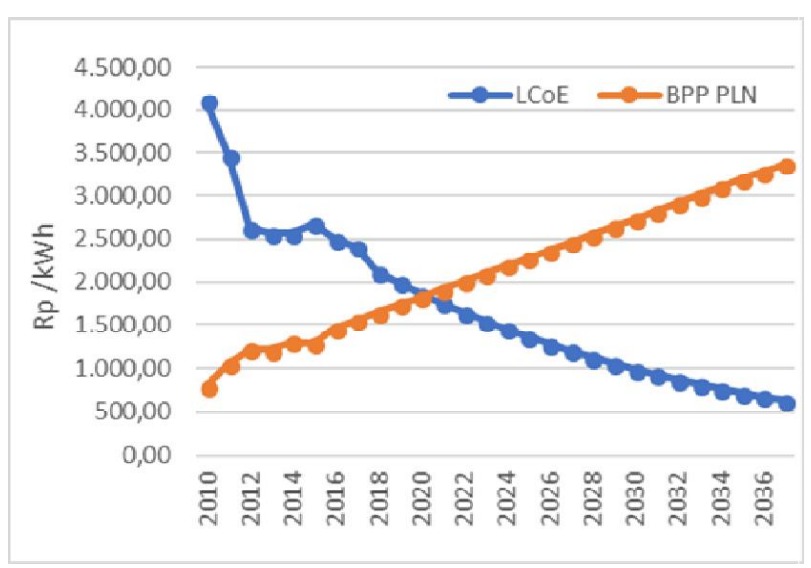

Fig 2. Grid Parity System in Banda Aceh 


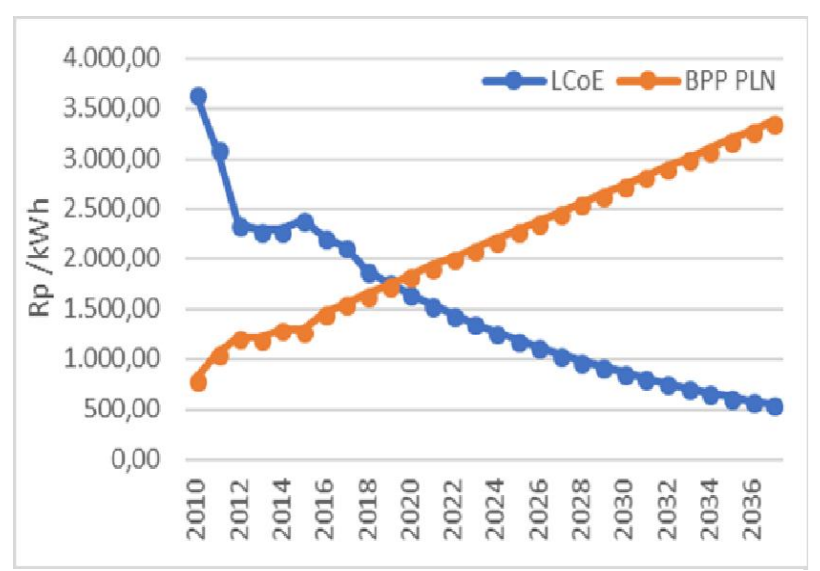

Fig 3. Grid Parity System in Jakarta

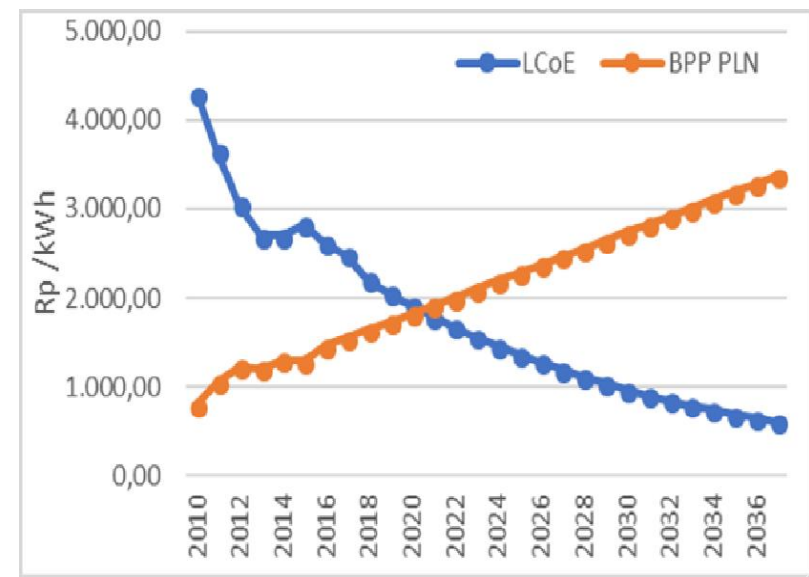

Fig 4. Grid Parity System in Balikpapan

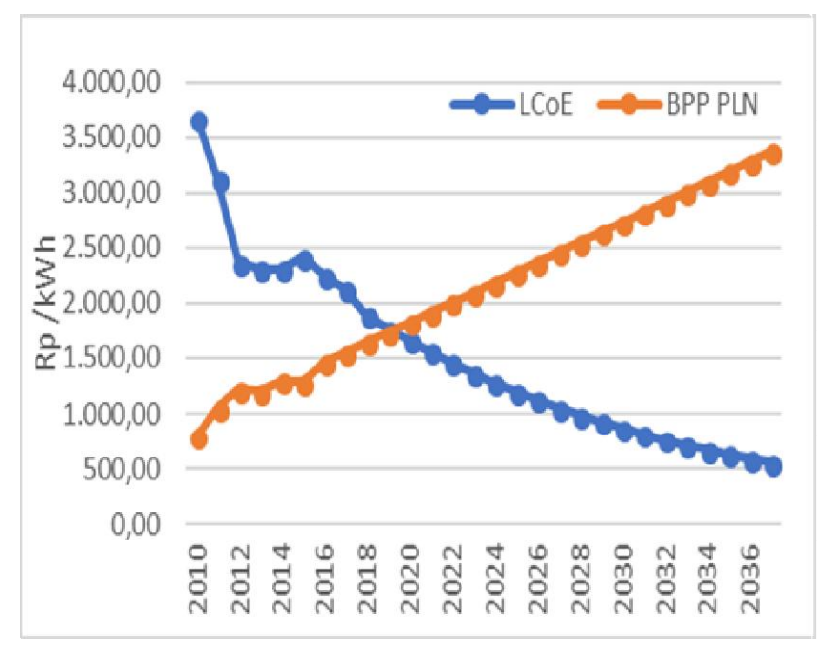

Fig 5. Grid Parity System in Manado

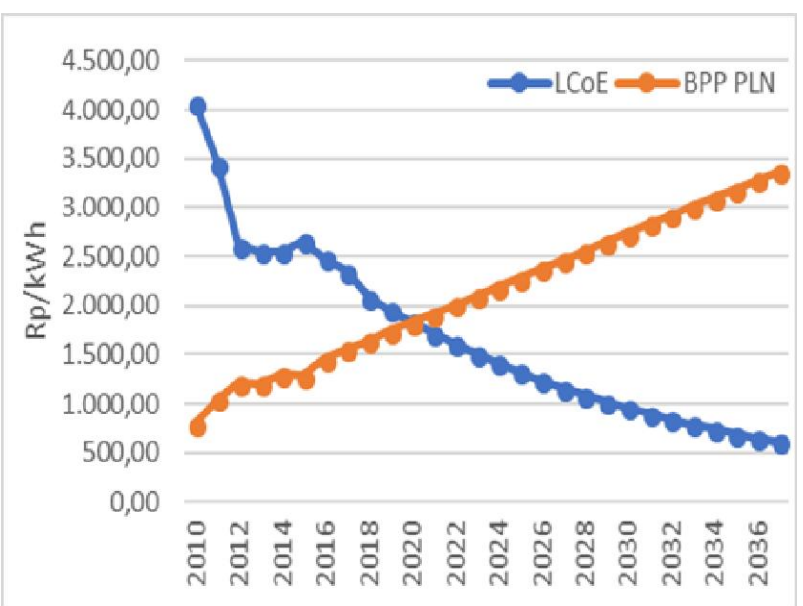

Fig 6. Grid Parity System in Jayapura

LCoE prices in the next 20 years is much cheaper than the BPP PLN. This becomes an economic opportunity for the community to take advantage of this moment considering that in the future Indonesia has demographic advantages so that society must be able to compete and wise to exploiting this opportunity. We will analyze the effect on economic parameter when the system is implemented in 2018 and at the time of the grid parity.

\section{a. Energy Production}

Tabel 1. GHI Each Region in Indonesia

\begin{tabular}{|l|c|c|c|c|c|}
\hline \multicolumn{1}{|c|}{ City } & Latitude & Longitude & Height & Wind Velocity & GHI \\
\hline Aceh & $5,6 \mathrm{~N}$ & $9,3,3 \mathrm{E}$ & $0,8 \mathrm{~m}$ & $2,9 \mathrm{~m} / \mathrm{s}$ & $4,52 \mathrm{kWhm}^{2}$ \\
\hline Jakarata & $-6,2 \mathrm{~N}$ & $106,9 \mathrm{E}$ & $5 \mathrm{~m}$ & $2,3 \mathrm{~m} / \mathrm{s}$ & $4,56 \mathrm{kWhm}^{2}$ \\
\hline Balikpapan & $-1,3 \mathrm{~N}$ & $116 \mathrm{E}$ & $7 \mathrm{~m}$ & $2,1 \mathrm{~m} \mathrm{~m}$ & $4,22 \mathrm{kWh} \mathrm{m}^{2}$ \\
\hline Manado & $1,5 \mathrm{~N}$ & $124,9 \mathrm{E}$ & $381 \mathrm{~m}$ & $1,4 \mathrm{~m} / \mathrm{s}$ & $5,28 \mathrm{kWhm} \mathbf{m}^{2}$ \\
\hline Jayapura & $-2,5 \mathrm{~N}$ & $140 \mathrm{E}$ & $152 \mathrm{~m}$ & $1,7 \mathrm{~m} / \mathrm{s}$ & $4,96 \mathrm{kWhm}^{2}$ \\
\hline
\end{tabular}

Manado is the most optimal city to implement this PV system because the influence of the global horizontal irradiance that occurs in Manado is highest compared to the other four cities. The complete in Table 1 shows the influence of the location of the coordinates of some of Indonesia's territory. GHI in a region will be affected by the coordinates of the region. The further the region from the equator, the higher GHI in that region. In addition, the altitude of the region from the sea surface and its wind speed will affect the intensity of rainfall that occurs. The higher the region from the surface of the sea, the rainfall rate will be lower, and as the wind speed increase, the clouds need longer duration to approach the land of the region. These factors will affect the duration of sunlight exposure to the region. From the five cities analyzed in the table, Manado has the largest GHI index compared to the other four cities. This is influenced by the height of Manado city which is very high from sea level and has low wind speed although the location of Manado's coordinates is not too far away from the equator. Furthermore, the table also shows that Balikpapan has the smallest GHI index compared to the 
other cities. This is because the location of Balikpapan is relatively near from the equator and the height of that region above the sea level is relatively low. Then, by look at opportunity of the system utilization, because Manado has the largest GHI, the city has the most potential to the utilize the photovoltaic system.

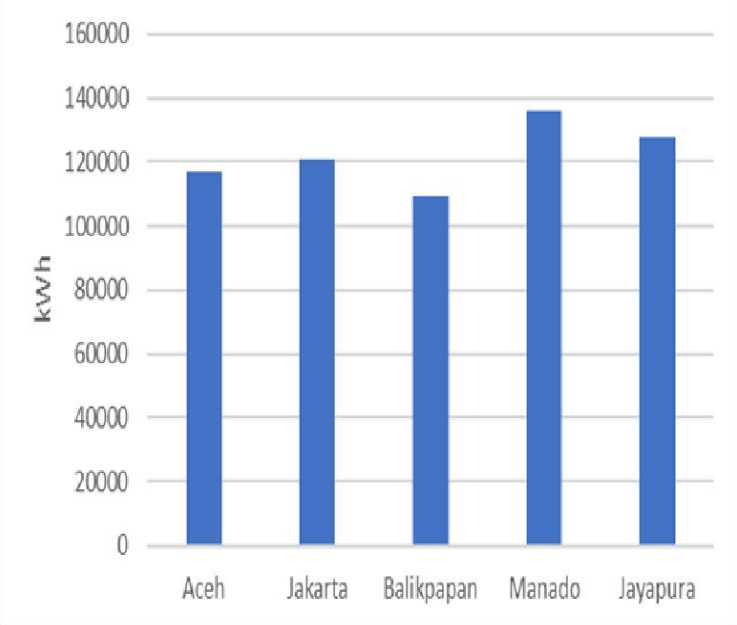

Fig 7. Energy Produced by Each Region

The Graphic show the energy potential generated by the system. the region need to be located further away from the equator, higher from the sea level and has lower wind speed. Then, the amount of energy that is generated by the system in a region can be a decisive factor for the government to prioritize development of facilities and infrastructure from many areas. This is because if the area has high energy potential but access to facilities and infrastructure to get to the area is constrained, then cost of investment of will be higher. The cost of investment will affect the price of the system and ultimately affect the LCoE from the PV system.

\section{b. Levelized Cost of Energy (LCoE)}

The lowest LCoE occurred in Jakarta and the highest occurred in Balikpapan. By comparing the LCoE value with PLN electricity tariff in 2018 that is Rp. $1467,37 / \mathrm{kWh}$, Manado and Jakarta have the value below the electricity tariff. Then it can be said that Jakarta and Manado meet the criteria to implement this system. While the other three cities unable to compete with the price of electricity tariffs if the system is made in 2018. This is due to several factors. In Balikpapan this inability occurs due to the potential of solar energy in Balikpapan is below the average potential of the Indonesian. Then in Aceh and Jayapura, this inability is caused by the initial cost to deliver goods that is quite expensive so that LCoE is still higher than the electricity tariff, even though Jayapura has higher potential than Jakarta. Furthermore, the actual LCoE produced by Manado will be much smaller compared to the present value because Manado has high GHI potential. However, due to the high initial costs, LCoE produced by Manado will match to the current value. Then it can be concluded that the initial cost will affect LCoE from the system but if a region has high solar energy potential then large initial cost can be covered by the amount of cash flow from the system. From the picture below we can see LCoE in each region.

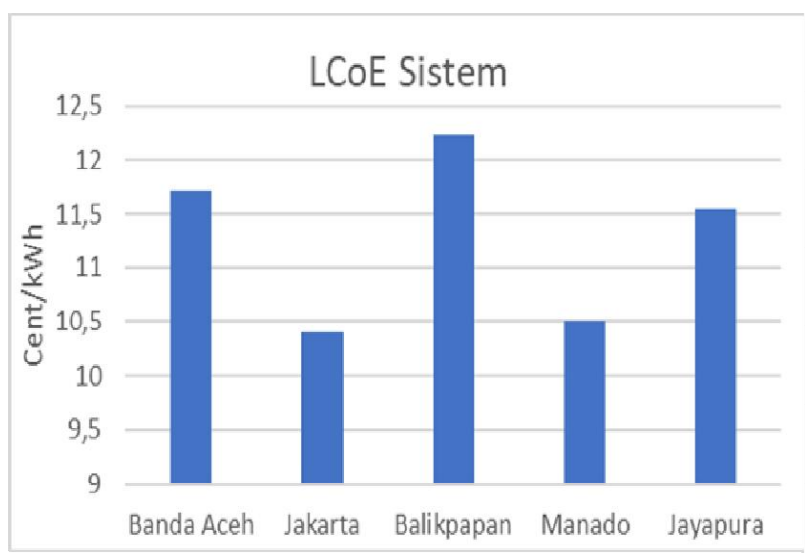

Fig 8. LCoE Each Region

When the system is implemented in the year of the grid parity in each region, $\mathrm{LCoE}$ of each region is, Banda Aceh 10,89 cent/kWh, Jakarta 10 cent/kWh, Balikpapan 11,18 cent $/ \mathrm{kWh}$, Manado 10,08 cent $/ \mathrm{kWh}$, and Jayapura $10.79 \mathrm{cent} / \mathrm{kWh}$. Then by comparing the LCoE system and the electricity tariff in the year of grid parity, the LCoE is below the electricity tariff. This means that the whole system can compete with electricity generated by PLN. More over the benefits of the PLN side and the government will also be obtained when the system is running in the year of grid parity. PLN can divert electricity supply from the residential sector to other more profitable sector sectors such as industry sector or public sector. On the government side, the government does not need to spend substantial energy subsidy on state budget anymore. The subsidy funds can be transferred to the construction of infrastructures in the remote area. When facilities and infrastructure are evenly distributed throughout Indonesia, the initial cost will also be suppressed and the opportunities to construct this PV system in various area in Indonesia will be greater. Chart shows the LCoE price of the system compared to the electricity tariff in the year of grid parity.

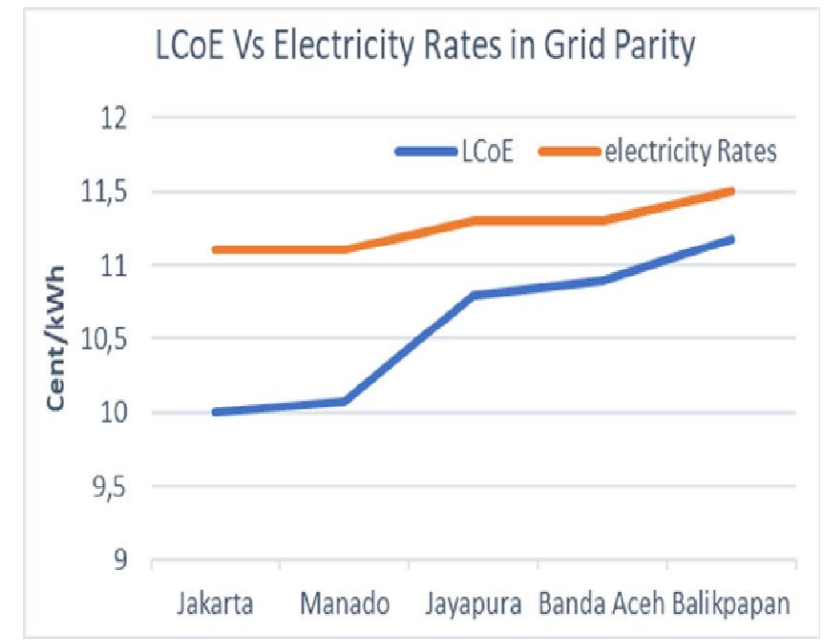

Fig 9. LCoE Vs Rates in Grid Parity 


\section{c. Net Present Value (NPV)}

The largest net present value (NPV) occurred in Manado and the smallest occurred in Balikpapan. This result shows that Manado is the most optimal city to implement this PV system. Then by consider the development of facilities and infrastructure in various regions in Indonesia, the cost of delivery and non-tool costs will be suppressed. When the initial cost becomes cheaper, the region with high solar energy potential will have even higher NPV. From the chart below, Manado in the present has more NPV than Jakarta, although Manado has higher initial cost than Jakarta. The NPV results of each city can be seen on graph

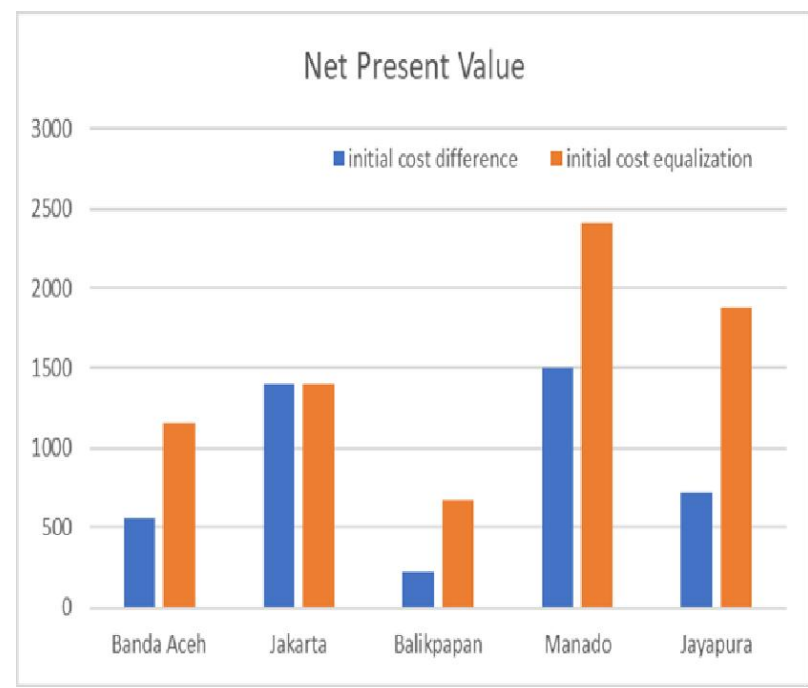

Fig 10. Net Present Value Each Region

\section{d. Payback Period}

The fastest payback time occurs in Jakarta and the slowest occurred in Balikpapan. Payback periods in each area is Banda Aceh 8 years, Jakarta 7.3 years, Balikpapan 8.3 years, Manado 7.4 years, and Jayapura 7.9 years. Then from these results, we can analyze that factor that affect the duration return of capital cost is the annual income obtained by the system. The higher the cash flow received by the system each year, the faster the payback period. This can be seen in Manado where it has high investment price but quick investment return time. Figure below shows the payback time of each city.

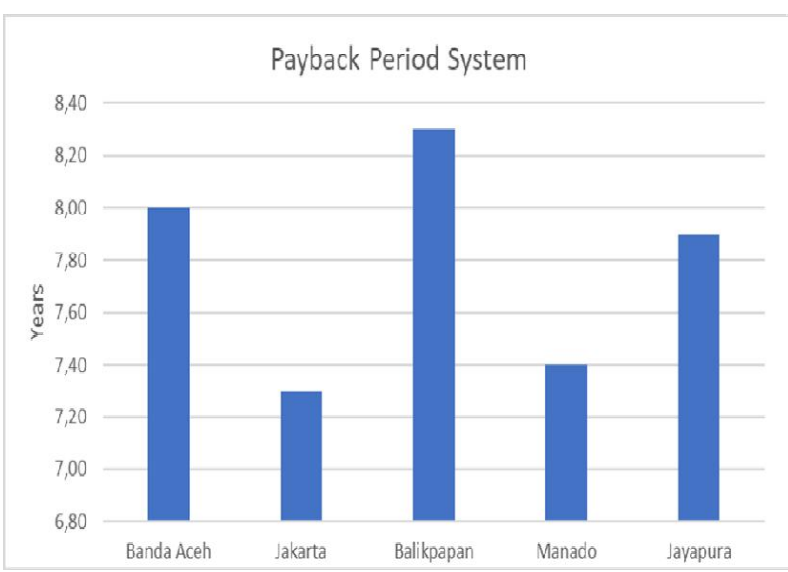

Fig 11. Payback Period Each Region

\section{Conclusion}

The initial cost affects the LCOE of the system but if an area has high solar energy potential then the initial cost may be covered by the amount of revenue from the system. And when the distribution of facilities and infrastructure is evenly distributed throughout Indonesia, the initial costs can be reduced and areas that have high potential of solar energy to be truly in optimal condition. When the system is implemented, the benefits are not only acquired by the system owner but also obtained by PLN and the government. PLN can distribute electricity to the industrial and other public sectors to gain more profit and government can divert subsidy funds that should be used to subsidize energy to develops facilities and infrastructure in various regions in Indonesia for the realization of equitable economic growth throughout Indonesia.

The Author would like to thank this work was supported and funded by "Hibah Panduan Penelitian Unggulan Perguruan Tinggi (PUPT) No 491/UN2.R3.1. HKP.05.00/2018“

\section{References}

1. Luigi T. De Luca, Propulsion physics (EDP Sciences, Les Ulis, 2009)

2. Krishadi Anangga, Economic Feasibility Comparison of ON-Grid Residential PV System in 5 cities Across Indonesia (Universitas Indonesia : 2017)

3. Fitria Yuliani, Analisa Skenario Optimasi Pemanfaatan Energi Listrik Tenaga Surya pada Sektor Industri (Universitas Indonesia : 2018)

4. John E. Hanke, Dean Wichiem Business Forecasting ( Pearson International Edition, United States,2008)

5. Ran Fu, dkk, U.S. Solar Photovoltaic System Cost Benchmark: Q1 2017 ( National Renewable Energy, 2017)

6. Rencana usaha penyediaan tenaga listrik PT PLN (Persero), 2010-2019. (2010). Kebayoran Baru, Jakarta: PT PLN (Persero).

7. Stephen Cornello, Cost Competitiveness of Residential Solar PV: The impact of net metering restrictions (Standforld Graduate School of Business, 2016)

8. Yoshihiro Yamamoto, Pricing Electricity From Residential Photovoltaic Systems: A Comparison Of Feed-Intariffs, Net Metering, and Next Purchase Sale (Takasaki City University Of Economics, 2012) 